\title{
Pengelolaan Keuangan dan Pembiayaan untuk Meningkatkan Kesejahteraan
}

\author{
Diyan Lestari \\ Manajemen, Fakultas Bisnis Institut Teknologi dan Bisnis Kalbis \\ Jalan Pulomas Selatan Kav. 22, Jakarta Timur \\ Email:diyan.lestari@kalbis.ac.id
}

\begin{abstract}
The community service activities is attemped to give contribution and share knowledge to society in order to improve their understanding and manage their life well. The community service is executed in Kampung Nelayan, Blok Eceng, Muara Angke. According to the research result, the fisherman do not understand how to manage their money well, and depend their funding on loan shark. The implementation of community service was well executed and attempt to improve society welfare.
\end{abstract}

Keywords: funding, kampong nelayan, money management,

\begin{abstract}
Abstrak: Kegiatan pengabdian kepada masyarakat dilakukan untuk memberikan kontribusi keilmuan kepada masyarakat agar masyarakat dapat memperoleh manfaat atas ilmu pengetahuan. Kegiatan pengabdian masyarakat ini dilaksanakan di kampung Nelayan, Blok Eceng, Muara Angke. Berdasarkan hasil riset, para nelayan tidak melakukan pengelolaan keuangan dengan baik dan masih sangat bergantung pendanaan dari tengkulak. Pelaksanaan kegiatan pengabdian kepada masyarakat dapat berjalan dengan lancar dan dilakukan dengan metode interkatif sehingga diharapkan dapat meningkatkan kesejahteraan kepada masyarakat Kampung Nelayan.
\end{abstract}

Kata kunci: kampung nelayan, pendanaan, pengelolaan keuangan

\section{PENDAHULUAN}

Krisis ekonomi pada tahun 1998 memberikan gambaran akan arti penting peran usaha mikro kecil dan menengah (UMKM). Peran pentingnya adalah tingkat ketahanan usaha kecil tersebut dibandingkan dengan usaha besar. Hal tersebut disebabkan karena permodalan UMKM cenderung berasal dari modal sendiri maupun modal keluarga serta tidak membutuhkan pembiayaan yang besar. Hal tersebut bertolak belakang dengan usaha besar yang membutuhkan pendanaan eksternal dengan biaya operasional yang relative besar. Hal tersebut menyebabkan tingkat ketahanannya menjadi lebih renah dibandingkan dengan UMKM.

Kawasan Muara Angke, dikenal sebagai kampong nelayan, dan juga tempat pelelangan, serta pelabuhan ikan. Banyak nelayan di kawasan Muara Angke yang masih dalam kondisi memprihatinkan. Selain itu, anak-anak nelayan juga tidak dapat mengenyam pendidikan yang layak. Anak-anak akan lebih memprioritaskan membantu orang tua mereka untuk bekerja di laut dibandingkan dengan belajar di sekolah, sehingga banyak dari anakanak yang terpaksa putus sekolah bahkan ada yang sejak di sekolah dasar dan tidak dapat melanjutkan pendidikannya.

Oleh karena itu, Muhammad Asrof cukup prihatin kondisi tersebut dan mendirikan Yayasan Rumpun Anak Pesisir (YRAP) di Kampung Nelayan, Blok Eceng, Muara Angke. Visi YRAP sendiri adalah melahirkan SDM professional yang memiliki masa depan berkualitas dan bermoral, memiliki kompetensi, berkepribadian luhur, dan peduli terhadap kehidupan berbangsa dan bernegara. Sementara misi YRAP adalah membantu meningkatkan pendidikan anak-anak kurang mampu, melakukan pembinaan dan pengembangan SDM anak-anak marginal, dan mempersiapkan anak-anak yang akan menjadi penerus bangsa untuk berperan serta sebagai manusia professional bagi Nusa Bangsa. Visi dan Misi tersebut ditujukan untuk dapat mencapai kualitas anak didik yang tidak hanya memiliki pengetahuan luas, akan tetapi juga memiliki akhlak, sikap, karakter, dan kepribadian yang bermoral.

Membantu orang tua dari kecil mengharuskan mereka lebih paham tentang bagaimana melakukan pengelolaan keuangan. Dengan latar belakang orang tua yang berprofesi sebagai pelayan dengan ekonomi lemah. Nelayan memungut ikan bersama 
keluarganya yang kemudian dijual, termasuk ikan yang tercecer dipungut kemudian dijual. Selain itu, untuk memenuhi kebutuhan ekonomi keluarga, beberapa keluarga terpaksa untuk menjadi buruh cuci gosok untuk menambah penghasilan. Selain itu, para nelayan juga sering menjual ikan ke tengkulak dengan harga murah karena setiap membutuhkan biaya, para nelayan akan meminta bantuan nelayan.

Oleh karena itu, sangat penting untuk memberikan pengetahuan yang cukup mengenai pengelolaan keuangan sejak dini untuk anak-anak nelayan dan juga para nelayan, dan yang lebih penting lagi adalah pemahaman mengenai sumber pembiayaan yang tepat untuk kegiatan usaha serta memenuhi kebutuhan sehari-hari sehingga keluarga para nelayan juga dapat lebih sejahtera.

Nketsiah (2018: 8) menyatakan bahwa gagalnya sebuah usaha kecil, pada dasarnya sering diakibatkan karena pengelolaan keuangan yang buruk, sehingga pengelolaan keuangan dan sumber pendanaan yang tepat akan sangat menunjang kesuksesan sebuah usaha. Begitu pula Jindrichovska (2013: 80) yang melakukan penelitian mengenai arti penting pengelolaan keuangan, jika usaha kecil ingin memiliki usaha yang berkelanjutan secara jangka panjang, maka usaha kecil tersebut perlu memperhatikan pengelolaan kauangannya.

Tidak hanya usaha kecil yang membutuhkan pengelolaan, individu juga perlu melakukan pengelolaan keuangannya agar dapat memenuhi kebutuhannya secara jangka panjang. Nelayan, tidak hanya merupakan sektor mikro, akan tetapi juga merupakan individu yang perlu mensejahterakan keluarganya. Putri \& Lestari (2019: 40) menyatakan bahwa pemahaman keuangan yang baik akan memberikan dampak pada pengelolaan keuangan yang baik dan diharapkan dapat meningkatkan kesejahteraan individu melalui meningkatnya alokasi aset, kewajiban, penghasilan, dan juga pengeluaran.

\section{METODE PELAKSANAAN}

Untuk menggali lebih jauh mengenai permasalahan mitra dan juga untuk memberikan solusi yang tepat, kegiatan pengabdian kepada masyarakat dilakukan dengan memberikan pelatihan interktif dengan topik pengelolaan keuangan dan pembiayaan untuk meningkatkan kesejahteraan.

Dalam menggali permasalahan mitra untuk memberikan solusi yang sesuai dengan kebutuhan mitra, sebelum pelaksanaan kegiatan pengabdian kepada masyarakat dilakukan kegiatan riset melalui penelitian kualitatif. Penelitian kualitatif merupakan sebuah penelitian yang merupakan suatu bentuk tindakan social dan menekankan pada cara individu - individu melakukan interaksi, dan membuat kajian atas pengalaman tersebut untuk lebih memahami berbagai fenomena social yang ada pada individu dan masyarakat (Mohajan, 2018: 2).

Hancock, Ockleford, \& Windridge (2007: 7), mendifinisikan penelitian kualitatif sebagai penjelasan atas fenomena sosial. Hal tersebut ditujukan untuk membantu peneliti lebih memahami kondisi sosial masyarakat terkait dengan lokasi aktivitas sosial, mengapa aktivitas tersebut dilakukan, dan kegiatan sosial yang dilakukan. Penelitian kualitatif biasanya akan membahas mengenai aspek sosial dan berusaha memecahkan masalah sebagai berikut: kenapa individu - individu melakukan aktivitas yang mereka pilih, melihat individu membuat keputusan atas opini dan juga attitude yang dibentuk oleh individu, bagaimana individu - individu dipengaruh oleh berbagai kejadian yang ada di sekitar mereka, dan bagaimana budaya diterapkan dan dikembangkan dalam suatu kondisi sosial.

Selanjutnya, kegiatan penelitian untuk menggali permasalahan mitra dilakukan melalui teknik triangulasi, yaitu kegiatan penelitian yang dilakukan dengan wawancara, observasibaik observasu langsung maupun tidak langsung, dan juga dokumentasi. Dalam penelitian ini, wawancara, dan observasi dilakukan secara langsung dengan harapan dapat memperoleh gambaran penelitian dengan lebih komprehensif dan mampu memberikan solusi yang tepat. Observasi dan wawancara dilakukan untuk memperoleh data primer yang terkait dengan aktivitas sosial yang dilakukan oleh keluarga nelayan, melakukan evaluasi terhadap kegiatan yang dilakukan, terutama terkait dengan bagaimana mereka melakukan pengelolaan keuangan dan keputusan pembiayaan. Sedangkan dokumentasi digunakan untuk melengkapi hasil wawancara dan hasil observasi.

\section{A. Sumber Data}

Penelitian ini menggunakan data primer untuk memperoleh gambaran dan informasi secara langsung dan akurat dari sumber informan secara langsung. Data primer diperoleh dari aktivitas wawancara secara langsung kepada para informan, dan juga pengamatan secara langsung di Yayasan Rumpun Pesisir dan kampung nelayan di Muara Angke. Untuk melaksanakan kegiatan wawancara, peneliti telah melakukan pengelompokan para informan yang akan diteliti, antara lain sebagai berikut: 1) Kepala Sekolah 
Yayasan Rumpun Anak Pesisir, yaitu Muhammad Asrof; 2) Siswa Sekolah dari Yayasan Rumpun Anak Pesisir; dan 3) Para Nelayan di Kampung Nelayan, Blok Eceng, Muara Angke.

Sedangkan data sekunder digunakan untuk memberikan kajian mengenai literatur dan juga datadata lainnya yang sudah diolah untuk melengkapi data primer agar memberikan penjelasan yang lebih detail mengenai berbagai fenomena yang diteliti.

\section{B. Fokus dan Lokasi Penelitian}

Penelitian ini memiliki beberapa batasan masalah agar penelitian yang dilakukan menjadi fokus dan terarah, serta memiliki pedoman dalam membahas hasil penelitian. Kegiatan pengabdian kepada masyarakat yang dilakukan fokus pada penggalian masalah dan memberikan informasi terkait dengan bagaimana individu - individu di Kampung Nelayan, Muara Angke malukukan pengelolaan keuangannya dan juga terkait dengan berbagai keputusan pembiayaan untuk mendanai usahanya dan juga untuk memenuhi kebutuhan hidup sehari-hari.

Lokasi kegiatan penelitian dan kegiatan pengabdian kepada masayarakat dilakukan di ruang kelas Yayasan Rumpun Anak Pesisir (YRAP) dan di salah satu rumah nelayan yang berlokasi di Kampung Nelayan, Blok Eceng, Muara Angke, Pluit, Jakarta Utara. Hal tersebut dilakukan untuk memperoleh data yang lebih sesuai, baik dari Kepala Sekolah, siswa YRAP, dan juga para nelayan.

\section{Yayasan Rumpun Anak Pesisir (YRAP)}

Yayasan Rumpun Anak Pesisir(YRAP) didirikan dengan tujuan untuk meningkatkan pengetahuan anak-anak yang tinggal di Kampung Nelayan sehingga mereka bisa mengenyam pendidikan yang lebih baik dengan harapan untuk dapat memperoleh kesejahteraan yang juga lebih baik. YRAP didirikan berdasarkan UU No. 23/ 2002 sebagai payung hukum yang mendasarinya. YRAP atau Yayasan Rumpun Anak Pesisir mendirikan sebuah lembaga edukasi Rumah Pintar Anak Pesisir (RPAP) pada tanggal 20 April 2003 dengan beberapa bentuk pendidikan yang ditawarkan, antara lain: pendidikan untuk anak usia dini, yaitu sekolah rintisan yang setara dengan PAUD, sekolah rintisan yang setara dengan Kejar Paket A, dan Taman Pengajian Alquran (TPQ).

Aktivitas dari Rumah Pintar Anak Pesisir ini adalah fokus pada kegiatan di bidang sosial dan masyarakat tanpa memandang perbedaan suku, ras, dan agama karena tujuan yang dicapai oleh YRAP jauh lebih luas dibandingkan hal tersebut, yaitu meningkatkan kesejahteraan masyarakat di Kampung Nelayan. Pendirian YRAP dan RPAP sendiri dilatarbelakangi oleh tingginya angka anak putus sekolah dan banyakya pekerja anak di Kampung Nelayan, Muara Angke, khususnya keluarga nelayan tradisional yang bertempat tinggal di bantaran Kali Adem, Muara Angke, Jakarta Utara.

Untuk melaksanakan aktivitasnya, RPAP memiliki dukungan dari para sukarelawan khususnya yang merupakan para pemerhati pendidikan dan memiliki komitmen serta kepedulian yang tinggi dalam mengembangkan sumber daya manusia di masyarakat pada segmen ekonomi marginal, khususnya terhadap kehidupan anak - anak. Rumah Pintar Anak Pesisir menyelenggarakan pendidikan gratis untuk para siswa-siswinya yang sebagaian besar merupakan anak-anak nelayan dengan latar belakang kondisi ekonomi yang lemah. Kegiatan operasional sekolah tersebut dipimpin oleh Bapak Muhammada Asrof S.H., yang juga adalah Sekretaris Umum YRAP, dan berbagai aktivitas yang ada di RPAP dibantu oleh 10 orang guru sukarelawan dengan mengandalkan bantuan dana dari para donatur, dana bantuan operasional sekolah dari pemerintah, dan juga dukungan dana sukarela dari para warga sekitar. Pada tahun 2017, RPAP tercatat memiliki jumlah siswa sebanyak 60 anak yang mengenyam pendidikan di PAUS, 70 siswa sekolah dasar, dan 50 siswa TPQ.

RPAP juga memiliki visi misi yang membantu mereka dalam menjalankan kegiatannya guna mempermudah mencapai tujuan yang sudah ditetapkan. Visis RPAP adalah melahirkan SDM professional, dengan masa depan yang berkualitas dan bermoral, memiliki kompetensi, berkepribadian luhur serta peduli terhadap kehidupan bangsa dan Negara. Sementara misi RPAP adalah (1) membantu meningkatkan pendidikan anak-anak kurang mampu, (2) melakukan pembinaan dan pengembangan SDM anak-anak marginal, dan (3) mempersiapkan anakanak yang akan menjadi pelurus Bangsa untuk berperan serta sebagai manusia professional bagi Nusa Bangsa. Visi dan Misi ini diarahkan kepada pencapaian kualitas anak didik yang bukan hanya memiliki pengetahuan yang luas, akan tetapi juga memiliki akhlak, sikap, karakter dan kepribadian yang bermoral.

\section{Profil Rumah Pintar Anak Pesisir (RPAP)}

Rumah Pintar Anak memiliki beberapa detail terkait dengan profil kegiatannya, antara lain sebagai berikut: 
Nama Yayasan: Yayasan Rumpun Anak Pesisir

Nama Kepala Sekolah: Muhammad Asrof, SH

Nama Sekolah: Rumah Pintar Anak Pesisir (RPAP)

Alamat Sekolah: Muara Angke, Blok H1 U RT 06/

RW. 01, Kel. Pluit, Kec. Penjaringan, Jakarta Utara 14450

Telp. : $021-41767062$

Email : : 1pa muaraangke@yahoo.co.id

Website: www.rumpunanakpesisir.or.id

Luas Tanah: $60 \mathrm{~m}^{2}$

Akses Internet: ada

Status Sekolah: rintisan

SK. Ijin Operasional: SK MENKUMHAM, Akta No. 7

No. SK Ijin : AHU - 7944.AH.01.04.2013

Tanggal SK. Ijin Operasional : 11-11-2013

Tanggal SK. Akreditasi: Akta No 7, 11 Nov 2013

NPWP: 03.334.937.4-047.000

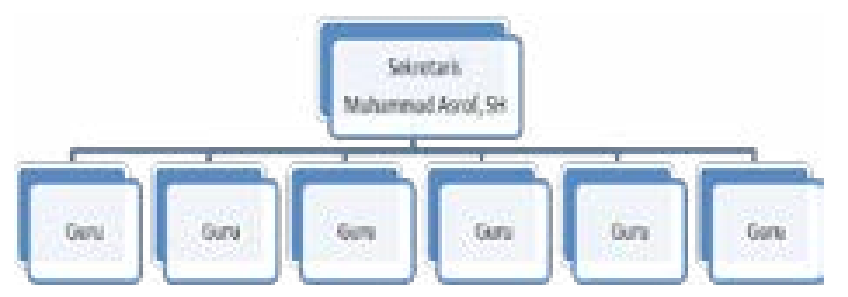

Gambar 1 Struktur Organisasi

Gambar 1 menjelaskan mengenai struktur organisasi dari Rumah Pintar Anak Pesisir (RPAP) di mana Muhammad Asro selaku Kepala Sekolah juga merupakan sekretaris Yayasan Rumpun Anak Pesisir yang dibantu oleh beberapa relawan guru - guru.

\section{E. Kampung Nelayan, Muara Angke}

Kampung nelayan, merupakan suatu perkampungan yang di mana sebagian besar masyarakatnya berprofesi sebagai nelayan. Profesi nelayan sendiri sangat erat dengan kondisi yang memprihatinkan dari sisi ekonomi. Terutama jika memiliki pengelolaan ekonomi yang buruk.

Dalam melaksanakan profesinya, para nelayan sering melakukan penjualan kepada para tengkulak di mana mereka memberikan. Kampung nelayan, dari kampung Blok Eceng di kawasan pelabuhan Muara Angke, Kelurahan Pluit, Kecamatan Penjaringan, Jakarta Utara merupakan mitra kedua dari kegiatan pengabdian kepada masyarakat. Lokasi kegiatan pengabdian kepada masyarakat ini dikenal dengan grey area atau daerah abu-abu yang pada dasarnya status mengenai kepemilikan tanahnya tidak jelas karena merupakan lahan garapan.

Pada kampung tersebut terdapat sekitar 300 kepala keluarga dengan hampir 850 jiwa penduduk. Karena berlokasi di grey area, maka tidak ada struktur organisasi birokrasi yang resmi di wilayah tersebut seperti halnya sistem RT/ RWpada umumnya dan digantikan dengan peran tokoh-tokoh lokal. Salah satu tokoh lokal yang berperan untuk membantu penduduk tersebut adalah Bapak Jatim yang berasal dari Indramayu, Jawa Barat.

Kawasan padat penduduk tersebut tidak memiliki sarana prasarana yang memadai layaknya perkampungan pada umumnya. Salah satu kendala paling besar adalah terkait dengan masalah sanitasi, khususnya pada penanganan air bersih. Air tanah pada lingkungan tersebut adalah air payau karena lokasinya yang dekat dengan laut. Air tersebut hanya dapat digunakan untuk memenuhi kebutuhan rumah tangga, tapi tidak untuk minum, dan memasak. Untuk kegiatan tersebut, seharusnya dibantu oleh PDAM untuk memenuhi kebutuhan masyarakat. Akan tetapi karena berlokasi di grey area, maka hal tersebut merupakan masalah besar. Masyarakat sekitar terpaksa harus membeli air yang dapat digunakan untuk minum dan memasak.

Pekerjaan mayoritas penduduk masih sama dari tahun ke tahun. Sebagian besar penduduk prianya baik dewasa maupun remaja memiliki profesi sebagai nelayan tradisional atau konvensional. Kegiatan melaut yang dilakukan juga masih sangat dipengaruhi oleh cuaca. Sehingga jika cuaca buruk atau tidak akan sangat mempengaruhi hasil nelayan dalam memperoleh ikan. Tengkulak juga merupakan salah satu faktor yang tidak menunjang perkembangan bisnis para nelayan di Muara Angke, dan menguasai hampir setiap sendi kehidupan para nelayan. Peran para tengkulak antara lain sebagai bank kredit, dan juga sebagai penyedia modal bisnis yang pada akhirnya terjadi lingkaran bisnis yang tidak sehat dan menjerat nelayan sehingga mengakibatkan terlilit utang abadi.

\section{F. Profil Kampung Nelayan}

Para nelayan yang ada di kampung nelayan merupakan mitra kegiatan pengabdian kepada masyarakat dengan beberapa detail informasi mengenai profil kampung nelayan sebagai berikut:

Nama kampung: Blok Eceng

Alamat: Muara Angke, Kel. Penjarinagan, Jakarta Utara

Nama tokoh lokal: Jatim (asal Indramayu, Jawa Barat)

Gambar 2 menggambarkan struktur organisasi Kampung Blok Eceng yang dibantu oleh Bapak Jatim dalam menjalankan kegiatan birokrasi dan membantu warga dalam berbagai kegiatan administrasi 


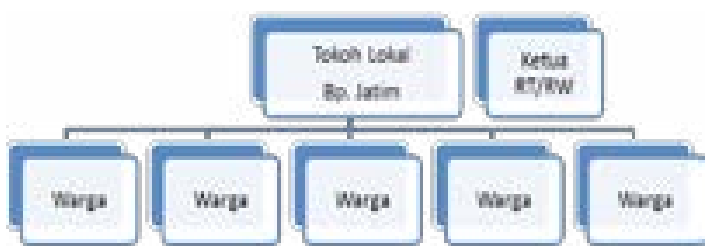

Gambar 2 Struktur Organisasi Blok Eceng

selayaknya Ketua RT/ RW di kampung tersebut. Bantuan warga untuk memperlancarkan kegiatan administrasi akan sangat membantu Bapak Jatim sehingga kegiatan warga dapat berjalan dengan lebih lancar.

\section{G. Kesejahteraan}

Warga yang sejahtera adalah warga yang bahagia. Kesejahteraan masyarakat tentunya adalah hal utama yang perlu dipertimbangkan oleh pemerintah. Kesejahteraan dapat didefinisikan sebagai kesuksesan, memiliki kegiatan yang mendukung majunya masyarakat, khususnya dalam hal keuangan. Secara umum, kesejahteraan masyarakat suatu negara diukur dengan menggunakan product domestik bruto (PDB) atau GDP yang merupakan kepanjangan dari gross domestic product (Urama \& Acheampong, 2013).

Untuk dapat mencapai suatu kesejahteraan, perlu adanya dukungan dari berbagai pihak akan adanya inovasi sosial yang telah dilakukan di berbagai negara di dunia untuk mengatasi kemiskinan yang terjadi. Akan tetapi tidak memang tidak mudah untuk dilakukan. Salah satu bentuk dari inovasi sosial adalah mengenai bagaimana masyarakat melakukan kegiatannya sehari-hari dan juga prinsip hidup yang diikuti, misalnya adalah penerapan adanya fair trade, semangat untuk terus belajar baik secara offline maupun online, transfer uang dengan berbasis digital atau berbagai kegiatan keuangan yang berbasis digital, penegakan hukum, penggunaan peralatan rumah tangga yang ramah lingkungan.

Selain itu, proses dalam menciptakan solusi untuk meningkatkan kesejahteraan masyarakat juga didasari adanya niat untuk berubah, penerapan berbagai perubahan yang dapat dimulai dari tingkat paling dasar, pengalokasian sumber daya, dan juga inovasi terkait dengan strktur sosial yang lebih mendukung adanya perubahan sosial yang lebih baik. Inovasi sosial juga memberikan kesempatan unik untuk berpikir lebih luas mengenai kegiatan usaha yang dimiliki oleh masyarakat secara umum dan bukan fokus pada perusahaan pribadi, keterlibatan bisnis di masyarakat, dan juga berbagai kegiatan filantropi dengan tujuan utama meningkatkan kesejahteraan masyarakat (Urama \& Acheampong, 2013).

\section{HASIL DAN PEMBAHASAN}

\section{A. Pendidikan Mitra}

Mitra PKM tidak memiliki tingkat pendidikan yang tinggi. Untuk mitra pada Yayasan Rumpun Anak Pesisir adalah siswa-siswi yang bersekolah di Rumah Pintar Anak Pesisir dengan rentang usia 12 tahun di mana mereka harus membantu keluarganya dan menjadi nelayan. Sedangkan untuk nelayan, memiliki tingkat pendidikan yang relatif terbelakang tidak mengenyam pendidikan tinggi, berusia antara 15 sampai dengan 60 tahun dengan kondisi ekonomi yang lemah.

\section{B. Ragam Kegiatan Mitra}

Selama 14 tahun, Rumah Pintar Anak Pesisir telah melakukan banyak hal dan berkembang serta berusaha untuk memenuhi kebutuhan masyarakat dan anak-anak pada khususnya di Muara Angke. Beberapa kegiatan yang dilakukan oleh RPAP antara lain sebagai berikut: 1) Menyelenggarakan pendidikan seperti pendidikan anak usia dini, taman pendidikan Alquran, perpustakaan, dan PKBM; 2) Rumpun Muda kreatif, yang antara lain meliputi sanggar anak (baik tari, teater, kreatifitas/ kerajinan tangan), forum anak; 3) Rumpun social, yaitu kegiatan social bersama seperti berbagi ceria (bantuan sosial bencana dan trauma healing), program aksi sosial orang tua asug; dan 4) Perlindungan anak dan perempuan.

\section{Permasalahan Mitra}

Keberadaan tengkulak membuat kondisi nelayan semakin buruk dan tidak bisa mandiri, serta terlilit utang abadi. Nelayan maupun anakanaknya tidak memahami sistem koperasi yang dapat membantu kondisi ekonomi nelayan. Sebelumnya sudah pernah didirikan Kelompok Usaha Bersama (KUB) yang pernah dirintis Sudin KPKP DKI Jakarta akan tetapi tidak berjalan dengan baik. Para nelayan tidak memiliki ide kreatif dan inovatif untuk mengolah hasil tangkapan ikan secara optimal sehingga dapat memperoleh hasil yang maksimal. Selain itu, kondisi cuaca yang tidak dapat diprediksi juga akan memberikan hasil laut yang kurang optimal karena sebagian besar nelayan masih menggunakan teknik tradisional.

Nelayan dan masyarakat tidak memiliki pemahaman akan arti pentingnya pendidikan formal, oleh karena itu tidak banyak ide yang dapat digunakan untuk meningkatkan kesejahteraan nelayan melalui 
kegiatan pengolahan ikan yang lebih baik. Orang tua nelayan juga tidak memperbolehkan anak-anaknya belajar di sekolah, akan tetapi lebih mengajurkan mereka untuk membantu bekerja sebagai nelayan. Nelayan juga tidak dapat melakukan pengelolaan keuangan dengan baik karena biaya solar yang relatif sangat mahal.

\section{Kebutuhan Nelayan}

Nelayan membutuhkan pemahaman yang lebih baik mengenai arti penting kreativitas dan inovasi sehingga dapat mengembangkan ide-ide bisnis untuk meningkatkan kesejahteraannya. Selain itu, nelayan juga perlu memahami arti penting pengelolaan keuangan dan bagaimana memperoleh modal dengan tidak melibatkan tengkulak, yaitu melalui hasil keuangan nelayan yang dikelola sedemikian rupa sehingga masih dapat menabung dan digunakan sebagai modal usaha atau sumber pendanaan lainnya selain dari tengkulak, seperti dibentuknya koperasi nelayan. Nelayan juga membutuhkan semnagat dan motivasi untuk terus berkembang dan maju.

\section{E. Peran Serta Mitra dalam Kegiatan}

Mitra memiliki peran aktif dalam menunjang keberhasilan kegiatan PKM. Mitra memiliki antusias dalam melakukan diskusi dan menyediakan tempat untuk melaksanakan kegiatan pengabdian kepada masyarakat dengan lancar.

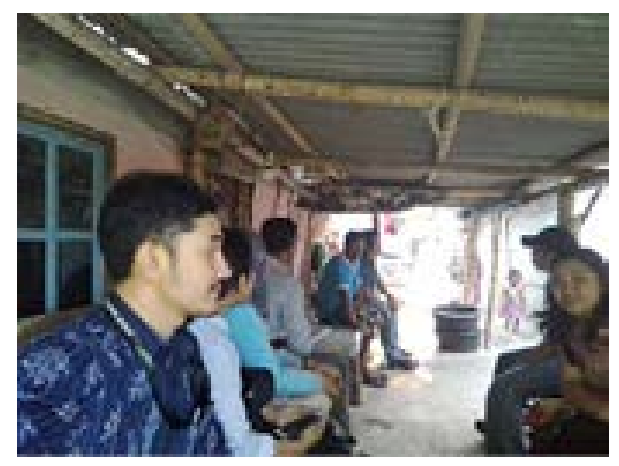

Gambar 3 Diskusi dengan Nelayan

Dengan adanya kegiatan ini, diharapkan masyarakat memiliki pemahaman lebih baik dan dapat meningkatkan kesejahteraannya melalui pengelolaan keuangan.

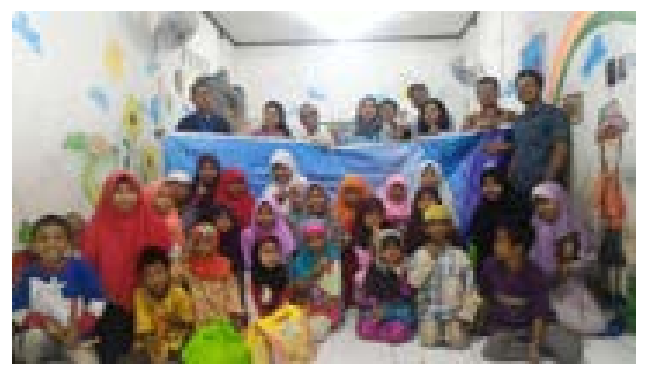

Gambar 4 Diskusi dan Pelatihan
Gambar 3 dan 4 menjelaskan mengenai pelaksanaan kegiatan pengabdian kepada masyarakat di mana para peserta sangat antusiuas dan berperan sangat aktif.

\section{F. Produk Kegiatan yang Bermanfaat}

Melalui kegiatan wawancara, obervasi, dan dokumentasi maka diperoleh berbagai wawan mengenai kebutuhan mitra dalam kegiatan pengabdian kepada masyarakat. Beberapa poin penting dalam kegiatan ini antara lain sebagai berikut: 1) Pelatihan mengenai pentingnya pengelolaan keuangan dan membuat laporan keuangan sederhana bagi para nelayan; 2) Pelatihan mengenai bagaimana melakukan pengelolaan keuangan untuk usaha baru; dan Pelatihan mengenai pembiayaan usaha untuk mendukung aktivitas nelayan.

\section{SIMPULAN}

Kegiatan pengabdian kepada masyarakat yang dilaksanakan di Kampung Nelayan, Blok Eceng, Muara Angke dapat berjalan dengan lancer sesuai denganjadwal yang telah ditentukan. Adapun beberapa manfaat yang diterima oleh para peserta kegiatan PKM antara lain sebagai berikut: peserta pelatihan memperoleh pengetahuan mengenai bagaimana melakukan pengelolaan keuangan sederhana untuk menopang hidupnya dan juga untuk mengembangkan bisnisnya, dan membahami bagaimana memperoleh pembiayaan usaha yang aman dan dapat membantu usaha nelayan di amsa depan.

\section{DAFTAR RUJUKAN}

Hancock , B., Ockleford , E., \& Windridge, K. (2007). An Introduction to Qualitative Research. The NIHR RDS $\mathrm{EM} / \mathrm{YH}$.

Jindrichovska, I. (2013). Financial Management in SMEs. European Research Studies, Volume XVI, Special Issue on SMEs.

Mohajan, H. K. (2018). Qualitative Research Methodology in Social Sciences and Related Subjects. Journal of Economic Development, Environment and People, Vol7, Issue 01, 23-48.

Nketsiah, I. (2018). Financial Management Practicesand Performance of SMEs in Ghana: The Moderating Role of Firm Age. Open Journal of Economics and Commerce, Volume 1, Issue 4, 8-18.

Putri, N. A., \& Lestari, D. (2019). Pengaruh Gaya Hidup dan Literasi Keuangan Terhadap Pengelolaan Keuangan Tenaga Kerja Muda di Jakarta. Akurasi: Jurnal Riset Akuntansi dan Keuangan, Vol 1, No.1, 31-42. 
Urama, K. C., \& Acheampong, E. N. (2013). Social Innovation

Creates Prosperous Societies . Retrieved January

5, 2020, from ssir.org: https://ssir.org/articles/entry/

social_innovation_creates_prosperous_societies 